\title{
Article \\ Influence of Murta (Ugni molinae Turcz) Powder on the Frankfurters Quality
}

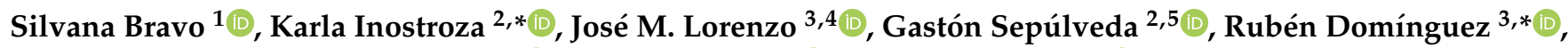 \\ Erick Scheuermann ${ }^{6}$, Erwin A. Paz ${ }^{7}{ }^{\circledR}$, John Quiñones ${ }^{2}{ }^{\circ}$, Eva María Santos ${ }^{8}{ }^{\circledR}$, Silvina Cecilia Andrés ${ }^{9}$, \\ Marcelo Rosmini ${ }^{10}$, Jorge Felipe Reyes ${ }^{11}$, Marco Antonio Trindade ${ }^{12}{ }^{\mathbb{D}}$ and Néstor Sepúlveda ${ }^{2} \mathbb{C}$
}

\section{check for}

updates

Citation: Bravo, S.; Inostroza, K.; Lorenzo, J.M.; Sepúlveda, G.;

Domínguez, R.; Scheuermann, E.; Paz,

E.A.; Quiñones, J.; Santos, E.M.;

Andrés, S.C.; et al. Influence of Murta (Ugni molinae Turcz) Powder on the Frankfurters Quality. Appl. Sci. 2021, 11, 8610. https://doi.org/10.3390/ app11188610

\section{Academic Editor:}

Alessandra Durazzo

Received: 24 August 2021

Accepted: 15 September 2021

Published: 16 September 2021

Publisher's Note: MDPI stays neutra with regard to jurisdictional claims in published maps and institutional affiliations.

Copyright: (C) 2021 by the authors Licensee MDPI, Basel, Switzerland. This article is an open access article distributed under the terms and conditions of the Creative Commons Attribution (CC BY) license (https:/ / creativecommons.org/licenses/by/ $4.0 /)$
1 Facultad de Ciencias Agrarias y Alimentarias, Instituto de Producción Animal, Universidad Austral de Chile, P.O. Box 567, Valdivia 5090000, Chile; silvana.bravo@uach.cl

2 Centro de Tecnología e Innovación de la Carne, Facultad de Ciencias Agropecuarias y Forestales, Center of Biotechnology on Reproduction, Scientific and Technological Bioresource Nucleus Universidad de La Frontera, P.O. Box 54-D, Av. Francisco Salazar, Temuco 01145, Chile; gsepulvedatruan@gmail.com (G.S.); john.quinones@ufrontera.cl (J.Q.); nestor.sepulveda@ufrontera.cl (N.S.)

3 Centro Tecnológico de la Carne de Galicia, Avd. Galicia no. 4, Parque Tecnológico de Galicia, 32900 Ourense, Spain; jmlorenzo@ceteca.net

4 Área de Tecnología de los Alimentos, Facultad de Ciencias de Ourense, Universidad de Vigo, 32004 Ourense, Spain

5 Programa de Doctorado en Ciencias Agroalimentarias y Medio Ambiente, Universidad de La Frontera, P.O. Box 54-D, Av. Francisco Salazar, Temuco 01145, Chile

6 Departamento de Ingenieria Química, Universidad de La Frontera, P.O. Box 54-D, Av. Francisco Salazar, Temuco 01145, Chile; ericks@ufrontera.cl

7 Institute of Agriculture, The University of Western Australia, Perth 6000, Australia; erwin.pazmunoz@uwa.edu.au

8 Área Académica de Química, Universidad Autónoma del Estado de Hidalgo, Carr. Pachuca-Tulancingo Km 4.5 s/n, Col. Carboneras, Mineral de la Reforma, Hidalgo 42183, Mexico; emsantos@uaeh.edu.mx

9 Centro de Investigación y Desarrollo en Criotecnología de Alimentos (CIDCA, CONICET-CICPBA-UNLP), Facultad de Ciencias Exactas, UNLP, 47 y 116, La Plata 1900, Argentina; scandres@biol.unlp.edu.ar

10 Department of Public Health, Faculty of Veterinary Science, National University of Litoral, Esperanza 3080, Argentina; mrosmini@unl.edu.ar

11 Department of Chemistry, Universidad Técnica Particular de Loja, San Cayetano Alto, Loja 100107, Ecuador; jfreyes@utpl.edu.ec

12 Departamento de Engenharia de Alimentos, Faculdade de Zootecnia e Engenharia de Alimentos, Universidade de São Paulo, Pirassununga, São Paulo 13635-900, SP, Brazil; trindadema@usp.br

* Correspondence: karla.inostroza@ufrontera.cl (K.I.); rubendominguez@ceteca.net (R.D.)

Abstract: Frankfurters are one of the most demanded meat products in the world due to their low cost and good taste. However, they contain up to $30 \%$ animal fat, which is negative for the consumer's health. Moreover, high-fat contents could also decrease frankfurter sensory properties, since it accelerates the rancidity of the products. This fact is highly dependent on the fatty acids composition since the unsaturation promotes oxidative reactions. Currently, strategies have been developed to replace animal fat with vegetable oils or the inclusion of new raw materials. The murta (Ugni molinae Turcz), an endemic plant in Chile, is a specie that contains high levels of flavonoids in its fruits and has a pleasant flavor, as well as a sweet and floral aroma. However, the effect of the addition of these fruits in the formulation of meat products has been scarcely studied. The present study aims to reduce the use of synthetic additives using natural ones (murta powder). Therefore, this research evaluated the influence of the inclusion of murta on the chemical, sensory, and instrumental parameters of traditional frankfurters. Three batches of frankfurters were manufactured: control sausages without additives (T0); samples with chemical antioxidant (T1); and with murta fruit powder (T2). The chemical composition, physicochemical parameters and sensory properties were determined. Frankfurters made with murta (T2) presented middle values in energy, moisture and sodium compared with control. Also, the reformulated sausages (T2) presented the lowest water holding capacity, redness ( $\left.\mathrm{a}^{*}\right)$ and yellowness and the highest values of fat and carbohydrates. Regarding fatty acids content, the most important changes were observed in the C18:0 and C14:0 (T2 presented the lowest values) and C18:2n-6 (T2 had the highest values), but minimal differences were 
observed in the total SFA, MUFA and PUFA content. Cholesterol content from T2 were similar to the control samples, and T1 presented the highest values. Although these differences, both chemical and nutritional quality of all frankfurters manufactured in the present study were very similar among treatments. Finally, according to the sensory analysis, T2 presented better acceptability and sensory characteristics compared with the other treatments $(p \leq 0.05)$. Therefore, the inclusion of murta in the production of frankfurters could be a strategy to improve the sensory characteristics of this product with minimal changes in chemical and nutritional properties. However, the effect of murta on oxidative stability and frankfurter shelf-life should be studied in depth in future research.

Keywords: native berries; natural additives; meat products; sensory attributes; healthy meat

\section{Introduction}

Nowadays, since consumers are increasingly aware of the relationship between food and health, there is a growing trend in the market towards the consumption of healthy foods, with improved nutritional characteristics and elaborated with functional ingredients [1-3]. Frankfurters are cooked-smoked emulsion-type sausage and one of the most popular meat products. In Chile, the national industry registered an increase in the production of sausage products, 9.73 million $\mathrm{kg}(3.7 \%)$ in 2019 , respected the previous year. The meat product mainly affected by the positive variation was the frankfurters (3.3\%) [4]. The wide consumption of frankfurters has become popular due to the characteristics of these types of products (low cost and good flavor/taste). However, the high fat amounts used in the traditional frankfurters and cooked sausages [5-7] resulted in oxidative degradation [8] and therefore, reduce the self-live during the storage and quality characteristics in terms of flavor, texture, and other functionalities [6]. In fact, these degradative reactions are considered the main deterioration process in the meat industry [8]. Synthetic antioxidants can be effective against lipid oxidation, but their use in meat products are related to a possible role in carcinogenesis [9]. This scenario favors innovation and implies the development of new processes and the use of alternative additives [10-15]. Therefore, it is important to develop functional meat products with a balance in fat content, fatty acid composition, cholesterol and sodium, without affecting their sensory quality and technological characteristics, contributing to their nutritional quality and consumer health $[16,17]$.

With this in mind, current consumers' preference for healthier and more natural foods has led to the inclusion of natural antioxidants in meat products to improve their shelf-life and reduce the use of synthetic antioxidants [18-20]. In fact, the tendency to reformulate meat products with natural ingredients is one of the topics studied during the last decades. This, together with a trend towards the reduction of animal ingredients and an increase in products of vegetable origin, makes a continual search for new natural sources of natural and potentially usable ingredients for the fortification of traditional products $[13,21,22]$. However, these reformulations can have both positive effects (reduce oxidation, increase shelf life, maintain sensory characteristics e.g., color) and can also have negative effects (strange odors, colors not associated with the meat product, technological problems or modification of the characteristics of the product) [21]. Therefore, it is vital to make an exhaustive study of the new sources of functional ingredients [21]. In this sense, myrtleberry, also known as Chilean guava, murtilla, or murta (Ugni molinae Turcz), is a Myrtaceae specie from southern Chile with promising composition [23]. The murta is cultivated by the Chilean indigenous ethnic Mapuche, who has historically appreciated this shrub due to its diverse benefits and used it as anti-inflammatory and pain relief. Furthermore, murta fruits have a pleasant taste and a sweet and floral aroma. Due to these characteristics, murta are used in the medical, cosmetic and food industries [24,25]. The biological properties of murta leaves and fruit are related to their high content in phenolic compounds [23], which determine also their high antioxidant activity [26,27]. In fact, murta extracts have demonstrated high in vitro antioxidant capacity and they 
have been incorporated into various cosmetic products to increase their durability [26]. Moreover, López de Dicastillo et al. [28] concluded that phenolic contents in U. molinae fruits were higher than values reported for other berries, such as plum, blackberries and strawberries. Also, the analysis of murta extract shows high antibacterial activity against both Gram-positive and Gram-negative bacterial strains [25]. Thus, murta fruit is a good source of bioactive compounds and an alternative to be incorporated in the reformulation of meat products.

Therefore, taking into account that it is necessary to identify new natural sources to reduce the use of synthetic additives in the food industry, the use of murta to obtain healthier products is proposed. In this context, the present study aimed to determine the effect of murta addition in frankfurters formulation on their chemical composition, physicochemical, and sensory properties.

\section{Materials and Methods}

\subsection{Sample Preparation}

The murta fruits (Ugni molinae Turcz) were obtained from 23-2-INIA ecotype (Instituto de Investigaciones Agropecuarias INIA Carillanca Murta Gene Bank). The ecotype used in this research was selected on agronomical and organoleptic characteristics [24]. The murta powder was supplied by the Food Science Laboratory of the Universidad de La Frontera, and its chemical composition analysis was carried out on SGS Chile Laboratory, according to the norms explained below. Briefly, for the preparation of murta powder, murta fruit was pulverized in a cold mill and passed through a $0.5 \mathrm{~mm}$ sieve. The chemical antioxidant "Plus Color", usually used in the frankfurter's preparation, was acquired by Prinal S.A. (Santiago, Chile). The chemical composition of both antioxidant sources is shown in Table 1.

Table 1. Chemical composition of antioxidants ingredients used in frankfurters formulation.

\begin{tabular}{ccc}
\hline Parameter & $\begin{array}{c}\text { Murta } \\
\text { (Ugni molinae Turcz) }\end{array}$ & Plus Color \\
\hline Energy value (Kcal/100 g) & 328.3 & 181 \\
Ash (\%) & 3.0 & 0 \\
Crude fiber (\%) & 7.1 & 0 \\
Fat (\%) & 1.5 & 0 \\
Moisture (\%) & 9.7 & 0 \\
Protein (\%) & 3.3 & 0 \\
Sodium (mg/100 g) & 51.2 & 20.662 \\
Total carbohydrate (\%) & 75.4 & 38.4 \\
\hline
\end{tabular}

Three different frankfurter batches ( $5 \mathrm{~kg}$ each) were prepared. The control was produced without an antioxidant (T0). The other two batches were formulated with different antioxidant types at the same concentration (T1: with Plus Color, a chemical antioxidant, and T2: frankfurter formulated using murta powder as antioxidant). The final concentration of each antioxidant was the same quantity of chemical antioxidant usually used in frankfurter manufacturing ( $0.53 \%$ of formulae). Table 2 shown the frankfurters formulations.

Briefly, the procedure to elaborate the different frankfurters treatments was as follows: lean raw pork and beef meat were mixed with salt, nitrites, antioxidants (murta powder of Plus Color), and species (pepper, garlic powder, and cumin). This mixture and bacon were grounded separately and were kept at $4{ }^{\circ} \mathrm{C}$. Then, lean meat, and bacon were homogenized for $2 \mathrm{~min}$ in a meat cutter, to obtain a meat batter. Ice water was added, and the meat batter temperature was kept below $8{ }^{\circ} \mathrm{C}$ during all processes. Then, the meat batter was stuffed into a collagen casing (diameter $22 \mathrm{~mm}$ ). The resulting frankfurters were cooked in a water bath at $75{ }^{\circ} \mathrm{C}$ until to obtain a frankfurter internal temperature of $72{ }^{\circ} \mathrm{C}$. After cooking, the frankfurters were cooled in ice, drained for $30 \mathrm{~min}$ and stored at $4{ }^{\circ} \mathrm{C}$ for subsequent analysis. All manufacturing process was replicated twice, with the same ingredients and 
processing conditions. Six samples of each treatment and manufacture replicate were used for the analysis.

Table 2. Formulation of frankfurters with and without antioxidants (expressed as percentage of total weight).

\begin{tabular}{cccc}
\hline \multirow{2}{*}{ Ingredients (\%) } & \multicolumn{3}{c}{ Treatments $^{\mathbf{1}}$} \\
\cline { 2 - 4 } & T0 & T1 & T2 \\
\hline Pork & 47.18 & 46.93 & 46.93 \\
Beef & 10.65 & 10.60 & 10.60 \\
Bacon & 18.26 & 18.17 & 18.17 \\
Water & 22.83 & 22.71 & 22.71 \\
Salt & 0.76 & 0.76 & 0.76 \\
Nitrites (Curaid ${ }^{\circledR}$ ) & 0.08 & 0.08 & 0.08 \\
Pepper & 0.08 & 0.08 & 0.08 \\
Garlic Powder $_{\text {Cumin }}$ & 0.08 & 0.08 & 0.08 \\
Antioxidant & 0.08 & 0.08 & 0.08 \\
\hline 1 T0: control without antioxidant, T1: chemical antioxidant (Plus Color), T2: natural antioxidant (murta).
\end{tabular}

\subsection{Proximate Composition}

The proximate composition of the frankfurters was performed $24 \mathrm{~h}$ after their manufacture in SGS Chile Ltd.a, member of the SGS Group (Société Générale de Surveillance), according to the following methods: moisture, 0I-CTS-LAB-200 based on Nch 841.Of78 [29]; protein, 0I-CTS-LAB-203 based on ISO procedure [30]; ash, I-CTS-LAB-201 based on AOAC Method 923.03 [31]; total carbohydrates, non-nitrogen extract expressed as total carbohydrates; crude fibre, Gafta Method 9 [32]; total fat, I-CTS-LAB-202 based on AOAC Method 920.39 [31]; sodium, AOAC Method 985.35 [33].

\subsection{Color and $p H$}

The $\mathrm{pH}$ of the frankfurters was determined directly using a portable $\mathrm{pH}$-meter for meat HI98163 (Hanna Instruments Inc., Romania). Measurements were performed in sixtuplicate at room temperature, changing the location of $\mathrm{pH}$ insertion in the frankfurter.

Color was measured directly in the internal part of the frankfurters using a Konika Minolta colorimeter Color Reader CR-10 (Konica Minolta Sensing, Inc., Tokyo, Japan), calibrated before measurements. The following CIE color coordinates were determined: redness $\left(a^{*}\right)$, yellowness $\left(b^{*}\right)$ and lightness $\left(L^{*}\right)$. Six determinations per sample were carried out.

\subsection{Water-Holding Capacity (WHC) and Cooking Loss}

The WHC of the frankfurters was determined using the compression method according to Dzudie et al. [34] with modifications. The frankfurters were ground in a food processor and blender model 123-750 W Moulinex (Moulinex, France) and $0.5 \mathrm{~g}$ of sample was placed between two qualitative filter papers Whatman (Grade 2, Cytiva, Marlborough, MA, USA) and then placed between two glass Petri dishes, with a force of $2250 \mathrm{~kg}$ applied for $15 \mathrm{~min}$. The WHC was performed by sixtuplicate, and calculated using the following equations:

$$
\begin{gathered}
\% \text { free water }=\{(W i-W f)\} \times 100 \\
W H C=100-\% \text { free water }
\end{gathered}
$$

where $W i$ is the initial weight of the ground sample and $W f$ is the final weight.

The cooking loss was also determined in each treatment of frankfurters by sixtuplicate by weight difference between uncooked and cooked samples. The frankfurters were cooked in a contact grill large double $S+S / S+S$ (MilanToast, Sulbiate, MB, Italy) at a central 
temperature of $70{ }^{\circ} \mathrm{C}$ determined by a handled probe. The cooking loss was calculated as follows:

$$
\% \text { cooking loss }=\{(W u-W c) / W u\} \times 100
$$

where $W u$ is the weight of the uncooked sample and $W_{c}$ is the weight of the cooked sample.

\subsection{Fatty Acid Analysis and Cholesterol}

For the fatty acid and cholesterol analysis, the frankfurters from each batch were minced using a domestic mincer in order to have homogeneous and manageable samples. After mincing, the samples were weighed and prepared for the subsequent analysis according to the method.

The lipids were extracted according to Folch methodology [35]. Fatty acid methyl esters (FAMEs) were formed using $800 \mu \mathrm{L}$ of n-hexane for analysis (Merck, Germany) and $1.3 \mathrm{~mL}$ of $2 \mathrm{~N}$ potassium hydroxide in methanol (Merck, Germany), added to each sample and then shaken magnetically for $30 \mathrm{~min}$. The supernatant was filtered with $0.5 \mathrm{~g}$ of anhydrous sodium sulfate for analysis (Merck, Germany), and centrifuge at $2000 \times g$ at room temperature for $5 \mathrm{~min}$. The FAMEs were analyzed using a gas chromatograph (Clarus 500 chromatograph, Perkin Elmer, MA, USA) equipped with a flame ionization detector (FID), split injection mode and autosampler. The FAME separation was carried out with a fused silica capillary column $\mathrm{SP}^{\mathrm{TM}} 2380(60 \mathrm{~m} \times 0.25 \mathrm{~mm} \times 0.2 \mu \mathrm{m}$ film thickness) (Supelco, PA, USA). One microliter of FAMEs extract was injected, and the column temperature program was: initial temperature set at $150{ }^{\circ} \mathrm{C}$, after $1 \mathrm{~min}$ the temperature was increased at a rate of $1^{\circ} \mathrm{C} \min ^{-1}$ to $168^{\circ} \mathrm{C}$, held for $11 \mathrm{~min}$, then increased at $6^{\circ} \mathrm{C} \mathrm{min}^{-1}$ to $230{ }^{\circ} \mathrm{C}$, and this temperature kept for $8 \mathrm{~min}$. The temperature of the detector and the injection port was $250{ }^{\circ} \mathrm{C}$ and Nitrogen was used as carrier gas. Individual FAMEs were identified by retention time using a standard mixture of 37 components FAME Mix C4-C24 (Supelco, PA, USA), and for the identification of conjugated linoleic acid (CLA) isomers, the standard octadecadienoic acid and conjugated methyl ester (CLA Sigma-Aldrich, Milwaukee, WI, USA), both analyzed under the same chromatographic conditions.

The cholesterol of the frankfurters was extracted by the procedure described by Fletouris et al. [36] and analyzed by gas chromatography in a Clarus 500 chromatograph, equipped with a column DB-17 $(30 \mathrm{~m} \times 0.25 \mathrm{~mm} \times 0.15 \mu \mathrm{m}$ film thickness, Agilent Technologies, Santa Clara, CA, USA). One microliter of cholesterol extract was injected under the next column temperature conditions: initial oven temperature was set at $250{ }^{\circ} \mathrm{C}$ and maintained for $10 \mathrm{~min}$, then increased to $260^{\circ} \mathrm{C}$ for $10 \mathrm{~min}$ at a rate of $5^{\circ} \mathrm{C} \mathrm{min}$ ma $^{-1}$ and hold for $18 \mathrm{~min}$. The temperatures of the detector (FID) and the injection port were $300{ }^{\circ} \mathrm{C}$ and $250{ }^{\circ} \mathrm{C}$, respectively. The cholesterol was identified and quantified using 5 - $\alpha$-cholestane (Sigma-Aldrich, Inc., Saint Louis, MO, USA), as internal standard.

\subsection{Sensory Evaluation}

An acceptance test was performed by 130 consumers (the percentage of female and male participation was 47.3 and $52.7 \%$, respectively, and the age range was $21-50$ years), that regularly consume this kind of frankfurters. All consumers were of legal age ( $>18$ years of age) and lived in the urban area of the city of Temuco, La Araucanía region. Each sausage treatment was cooked in an electrical contact grill large double S + S/S + S (MilanToast, Sulbiate, $\mathrm{MB}$, Italy) pre-heated at $150{ }^{\circ} \mathrm{C}$ and cooked the frankfurters until reached a central temperature of $70{ }^{\circ} \mathrm{C}$ determined by a handled probe. Samples were cut into cubes $(2 \mathrm{~cm} \times 2 \mathrm{~cm} \times 2 \mathrm{~cm})$, wrapped in aluminum foil, and assigned a random code number of two digits to identify each sample. Then immediately presented to the consumers in plastic dishes. Unsalted crackers and mineral water were provided to the consumers to clean their mouths between samples. The consumers' analysis was carried out under controlled conditions in a room with white light in the Meat Center for Technology and Innovation of the University of La Frontera, according to NCh-ISO6658:2016 [37]. The samples were evaluated in a single session. The information provided to the consumer was that they would evaluate three different frankfurters and the indications to do it. All 
the consumers were informed about the aim of this study and sign a list of participation. The first instruction was to smell the samples immediately after opening the wrapped aluminum container and to evaluate odor. Then, the consumers were requested to taste the samples and evaluate their flavor, tenderness, and overall acceptability. Each consumer evaluated the four different attributes for each sample: odor, flavor, tenderness, and overall acceptability on 8-point category scales ranging from dislike extremely (1), dislike very much (2), dislike moderately (3), dislike slightly (4), like slightly (5), like moderately (6), like very much (7) and like extremely (8). In this case, the category scale was of 8 points because the intermediate point corresponding to "neither like nor dislike" was excluded to stimulate a specific response. Consumers very often tend to use this point when it is available [38]. The goal of eliminating this point is because the distance between each category of the scale should be the same [39], and it was considered that the distance between 'dislike slightly' and 'like slightly' was double that between the other contiguous categories. In the session, each consumer evaluated six samples (two from each treatment). The frankfurters were served following a randomized design for limit carry-over effects.

\subsection{Statistical Analysis}

The statistical analysis was performed using the SPSS v.25 software for Windows (IBM Inc., Chicago, IL, USA). Six samples by each batch and manufacture replica were used in each analysis. To evaluate the statistical significance of the effect of the different frankfurter formulations in proximate composition, physicochemical properties, fatty acid composition and sensory analysis, a one-way analysis of the variance (ANOVA) was performed. The formulation was assigned as fixed effect and replication as a random effect. Tukey's post-hoc test was applied for comparison of means and the results were expressed as mean values and standard deviation. The differences were considered significant at $p \leq 0.05$.

\section{Results and Discussion}

\subsection{Proximate Composition and Physicochemical Parameters}

The production and consumption of frankfurters have led researchers and industry to focus to develop new technologies for the preparation of these sausages with reduced fat, vegetable additives, fiber incorporation etc. $[1,5,6,40,41]$ being an opportunity to improve the nutritional quality of the final product and offer to the consumers a healthy and functional meat product. In this study, the reformulation of frankfurters implied significant changes in the proximate composition and energy values of the frankfurters (Table 3).

Table 3. Energy value and proximate composition of frankfurters.

\begin{tabular}{|c|c|c|c|c|}
\hline \multirow{2}{*}{ Parameter * } & \multicolumn{3}{|c|}{ Treatments $^{1}$} & \multirow{2}{*}{$p$-Value } \\
\hline & T0 & T1 & T2 & \\
\hline \multicolumn{5}{|c|}{ Proximate Composition (g/100 g) } \\
\hline Moisture & $60.50 \pm 1.04^{a}$ & $56.25 \pm 0.71^{c}$ & $58.63 \pm 0.16^{b}$ & 0.000 \\
\hline Protein & $14.60 \pm 0.09$ & $15.23 \pm 0.68$ & $14.35 \pm 0.70$ & 0.221 \\
\hline Fat & $21.83 \pm 0.19^{b}$ & $23.00 \pm 0.21^{\mathrm{a}}$ & $23.21 \pm 0.72^{\mathrm{a}}$ & 0.001 \\
\hline Total carbohydrate & $0.77 \pm 0.05^{b}$ & $0.64 \pm 0.02^{\mathrm{c}}$ & $0.94 \pm 0.04^{\mathrm{a}}$ & 0.000 \\
\hline Ash & $2.07 \pm 0.08$ & $2.12 \pm 0.04$ & $2.05 \pm 0.09$ & 0.248 \\
\hline Crude fiber & $0.42 \pm 0.04$ & $0.44 \pm 0.03$ & $0.41 \pm 0.01$ & 0.223 \\
\hline Energy value (Kcal/100 g) & $258.20 \pm 1.47^{c}$ & $281.50 \pm 0.42^{\mathrm{a}}$ & $271.42 \pm 0.42^{b}$ & 0.000 \\
\hline Sodium $(\mathrm{mg} / 100 \mathrm{~g})$ & $448.50 \pm 1.05^{c}$ & $668.33 \pm 9.30^{\mathrm{a}}$ & $458.78 \pm 1.10^{b}$ & 0.000 \\
\hline
\end{tabular}

${ }^{1}$ T0: control without antioxidant, T1: chemical antioxidant (Plus Color), T2: natural antioxidant (murta). Different letters in the same row indicate significant differences ( $p \leq 0.05$; Tukey test); ${ }^{*}$ All parameter values were presented as mean \pm standard deviation.

The frankfurter treatment with the addition of murta presented middle values in energy, moisture and sodium between the control treatment and frankfurters formulated with Plus Color. In samples from control treatment were observed the lowest values of energy and sodium and the highest values of moisture $(p \leq 0.05)$. The addition of the chemical 
antioxidant (Plus Color) significantly increased the energy value and sodium $(p \leq 0.05)$, while the protein content show also slight increase $(p>0.05)$. In these frankfurters, the sodium amount increased considerably $(49 \%)$ in comparison with the control treatment and $(45.7 \%)$ sausages with murta. On the other hand, a significant increase $(6.3 \%)$ was observed in fat content $(p \leq 0.05)$ in treatments when antioxidant (chemical or murta) was added. The fat is also responsible for the energy value, and in this sense, the lowest fat value observed in the control treatment resulted in the lowest energy value in these samples. No differences were observed in ash and crude fiber between treatments $(p \geq 0.05)$.

The values observed in the present study for the different proximate composition parameters agree with those reported previously by other authors. Multiple studies [5,41,42] which analyzed the effect of animal fat reduction or replacement by other ingredients in frankfurters reported moisture values of $55-66 \%$, fat between $14-24 \%$ and protein between $11-18 \%$. Although our values agree with the ranges reported by these authors, it is also important to highlight that the composition of raw materials and the differences in the Frankfurters' formulation between studies are the main source of variations among the data observed in each study.

Regarding the effect of the reformulation, we observed that the energy value decreased with decreasing the fat contents in the frankfurters among treatments. Thus, the lowest fat content and energy value during frankfurters analysis was observed in T0 samples $(21.83 \%$ and $258.20 \mathrm{Kcal} / 100 \mathrm{~g}$, respectively). The moisture presented the opposite trend in comparison with fat. The reformulated frankfurters (T2 and T3) had lower moisture content than the control (T0). Therefore, inverse and significant behavior were observed in the proximate (moisture and fat) composition according to the formulation. The higher moisture content in the control sausages determines that the rest of the parameters have a lower content in percentage terms, which explains the results obtained in our study. Moreover, murta addition also produced an increase in the total carbohydrate content of the frankfurters due to the high content on the fruit (75.4\% total carbohydrate; Table 1$)$. However, although the murta contains about $7 \%$ of fiber, the reformulation did not influence ash $(2.05-2.12 \%)$ nor crude fiber $(0.41-0.44 \%)$. The low amounts of murta used in the reformulation $(0.53 \%)$ could be the reason for this behavior. As a general conclusion, despite the significant differences that we have just mentioned, it should be noted that the proximate composition of the frankfurters of the different formulations was very similar, and the variations were minimal ( $<4 \%$ in moisture, $<1.5 \%$ in fat, $0.3 \%$ in carbohydrates), while the rest of the parameters did not vary significantly. This agrees with the results previously observed by other researchers who found that the addition of fruit extract of strawberry tree (Arbustus unedo L.) and dog rose (Rosa canina L.) or additives did not affect the chemical composition of frankfurters [1]. Another study also indicated that the chemical composition of the frankfurters was affected by the reduction/replacement of fat content more than the addition of fruits extracts or additives [40], which agree with the findings obtained in the present manuscript.

On the other hand, taking into account that the fat is the main parameter that influences the energy content of foods ( $9 \mathrm{Kcal} / 100 \mathrm{~g}$ instead $4 \mathrm{Kcal} / 100 \mathrm{~g}$ in carbohydrates or proteins), it is expected that the fat content differences resulted also in differences in the energy content. In fact, a direct relation between fat and energy content was observed in our study, where the samples with the lowest fat values (T0) also presented the lowest energy values. This direct relation between the fat content and energy value was previously reported by other authors $[5,40,42]$, who confirm our findings. Therefore, in the present research, the differences in energy values were due to the differences in fat content between samples. In the Chilean warning system implemented in June of 2019, the steps for discouraging food consumption with high content of unhealthy nutrients (sugar, saturated fat, sodium, and calories), consist into identifying the products that exceed pre-established thresholds and must include the octagonal signs with the expression "High in ... " for each nutrient. Regarding the calories, the threshold is $275 \mathrm{kcal} / 100 \mathrm{~g}$ [43]. In this sense, in the present study, only the frankfurters formulated with chemical antioxidant (Plus Color; T1) need to 
include the octagonal sign for calories since the control and murta reformulated samples presented lower energy values than the threshold (258.2 and 271.4 Kcal/100 $\mathrm{g}$ for T0 and $\mathrm{T} 2$, respectively).

Our findings show that murta addition only increased the sodium content by $2.29 \%$ and the chemical antioxidant increased by $49 \%$ of sodium compared with the control treatment. This result was expected since the sodium content of chemical antioxidant (20.7 g/100 g, Table 1) was extremely higher than those found in the murta $(51.2 \mathrm{mg} / 100 \mathrm{~g}$, Table 1). Even though it is important to note that the sodium values found in the present study (ranged from 448 to $668 \mathrm{mg} / 100 \mathrm{~g}$ ) were significantly lower than those reported by other authors in frankfurters [1,42]. Therefore, and taking into account that health institutions recommend the reduction of the sodium intake [16,44,45], it is important to highlight that the inclusion of murta could be an excellent replacer for chemical antioxidant since minimal influence in the sodium content was observed.

The two types of antioxidants used in the frankfurter formulation had different effects on their physicochemical parameters (Table 4). The samples from control and murta treatments had the lowest $\mathrm{pH}$ values (6.30 and 6.36, respectively), while the $\mathrm{pH}$ increased significantly with the incorporation of chemical antioxidant Plus Color $(p \leq 0.05 ; 6.66)$. The variation in $\mathrm{pH}$ value depends on the ingredients in the formulation of the frankfurters. In our study, the $\mathrm{pH}$ increase with the incorporation of chemical antioxidant could be due to Plus Color composition and their specific $\mathrm{pH}$ (Plus Color $\mathrm{pH}$ range of 7.0-8.0). Also, the addition of synthetic antioxidants to frankfurters formulation, like BHT (butylated hydroxytoluene), shown a higher $\mathrm{pH}$ value than frankfurters containing pomegranate juice concentrates or pomegranate rind powder [9], which agree with our findings. Similarly, as occurs in our study, the addition of different fruit extracts did not influence the $\mathrm{pH}$ values in a previous study [1]. On the other hand, Choi et al. [6] mentioned that the $\mathrm{pH}$ value of frankfurters elaborated with vegetable oil and fiber increased because they contain minerals (principally iron, phosphorus, and calcium).

Table 4. Physicochemical parameters of frankfurters.

\begin{tabular}{|c|c|c|c|c|}
\hline \multicolumn{2}{|c|}{ Parameters * } & \multicolumn{2}{|c|}{ Treatments ${ }^{1}$} & \multirow[t]{2}{*}{$p$-Value } \\
\hline & T0 & T1 & T2 & \\
\hline $\mathrm{pH}$ & $6.30 \pm 0.09^{b}$ & $6.66 \pm 0.04^{\mathrm{a}}$ & $6.36 \pm 0.12^{b}$ & 0.000 \\
\hline WHC & $83.97 \pm 0.64^{\mathrm{a}}$ & $84.52 \pm 1.30^{\mathrm{a}}$ & $81.38 \pm 1.16^{b}$ & 0.000 \\
\hline CL & $2.35 \pm 0.83$ & $4.94 \pm 2.61$ & $4.81 \pm 1.87$ & 0.198 \\
\hline \multicolumn{5}{|c|}{ Color parameters } \\
\hline Redness $\left(\mathrm{a}^{*}\right)^{1}$ & $16.58 \pm 0.97^{b}$ & $18.77 \pm 0.41^{\mathrm{a}}$ & $15.71 \pm 0.69^{b}$ & 0.000 \\
\hline Yellowness $\left(\mathrm{b}^{*}\right)$ & $11.33 \pm 0.34^{\mathrm{a}}$ & $11.02 \pm 0.39^{\mathrm{a}}$ & $10.17 \pm 0.54^{b}$ & 0.001 \\
\hline Lightness $\left(\mathrm{L}^{*}\right)$ & $53.65 \pm 1.30^{\mathrm{a}}$ & $51.33 \pm 1.60^{b}$ & $52.27 \pm 1.44^{\mathrm{ab}}$ & 0.035 \\
\hline
\end{tabular}

${ }^{1}$ T0: control without antioxidant, T1: chemical antioxidant (Plus Color), T2: natural antioxidant (murta). WHC: Water holding capacity; CL: Cooking loss; Different letters in the same row indicate significant differences $\left(p \leq 0.05\right.$; Tukey test); ${ }^{*}$ All parameter values were presented as mean \pm standard deviation.

Water holding capacity (WHC) was reduced by the addition of murta antioxidant $(p \leq 0.05)$. T0 and T1 had the highest WHC. These results showed that the addition of murta did not improve the WHC, despite the high-quality pectin contained in murta fruit. However, inulin and pectin have been scarcely used in cooked meat products, despite the technological characteristics of dietary fibers, like the capacity to hold water, interact with fat, and provide texture. Thus, the dietary fibers are a candidate to be used as fat substitutes [25]. Other ingredients used in the frankfurters formulation, like fibers, increased WHC, and this result is due to the level of fat and fiber addition. According to López-López et al. [46] WHC of some dietary fibers is related to the polysaccharides characteristics, specifically type and amount; in this sense, large particles are associated with open structures that improve the properties of hydration and fat absorption capacity. 
However, the low amount of murta added to the reformulated frankfurters could explain the results observed in the present research.

The cooking loss (CL) did not show significant differences between control and treatments with chemical and natural antioxidant $(p \geq 0.05)$. Although this, the reformulated sausages presented higher CL ( $4.94 \%$ and $4.81 \%$ for $\mathrm{T} 1$ and $\mathrm{T} 2$, respectively), than control $(2.35 \%)$. The CL of the frankfurters depends on the cooking temperature, cooking time, the ingredients, and fat amount in the products [6]. In the present study, the formulations were very similar (only $0.53 \%$ of murta or chemical antioxidant was added), and the processing parameters (temperatures, times, etc.) were the same for all treatments, which could explain the lack of significant differences between control and reformulated samples. Other authors reported differences in cooking loss frankfurters with reduced-fat $[6,41]$ and with fiber incorporation [47], but in these cases, the proportion and/or the type of ingredients reformulation were changed between treatments.

Color plays an important role in the consumer perception and preferences in modified meat products $[10,11]$, like frankfurters. In this research, the instrumental analysis showed that the color properties $\left(\mathrm{a}^{*}, \mathrm{~b}^{*}\right.$ and $\left.\mathrm{L}^{*}\right)$ of the frankfurters were affected by the reformulation (Table 4). Similar findings were observed previously by other authors, who reported a significant influence of the plant extract addition on frankfurters color [1]. The highest $a^{*}$ value was observed in frankfurters formulated with chemical antioxidant (Plus Color), while samples from control and murta treatments presented lower values $(p \leq 0.05)$. The highest $b^{*}$ value was found in control samples and frankfurters with the addition of chemical antioxidant Plus Color, being these frankfurters more yellowness $(p \leq 0.05)$, compared to frankfurters with murta added. Finally, in contrast to redness, the lowest lightness (L)* value was observed in the samples from T1 treatment (51.33), while the control frankfurters had the highest values (53.65) and murta samples presented intermediate values $(52.27 \pm 1.44)$.

It was expected that frankfurter formulated with murta presented the highest value in redness, due to the characteristic red color of this fruit. However, the frankfurters formulated with murta exhibited the lowest redness $\left(\mathrm{a}^{*}\right)$ values, without significant differences between control and murta treatments $(p \geq 0.05)$. These findings could also be related to the low content of murta powder added in the sausage formulation. Similarly, sausages from murta treatment show the lowest $b^{*}$ value, in comparison with control and synthetic antioxidant treatment. The decrease in $b^{*}$ values attests to greater clarity in terms of cleanness or clearness [48]. Another possible explanation for the differences in frankfurter color can be the changes in murta pigments, which can suffer degradation due to high temperatures during frankfurters manufacturing. The levels of anthocyanins can explain the different intensity in the fruit color, especially for murta, which is red-rose, in comparison with other Chilean berries [49].

Regarding L* values, Fernández-López et al. [2] reported that this parameter in meat products are related to fat and moisture content (mainly due to the water and fat in the surface of these products affects light reflection) because fat and moisture make the product lighter colored. In our case, the lightness was related to the moisture content. The control (T0) treatment, with the lowest fat and highest moisture contents, showed the highest $\mathrm{L}^{*}$ values than the samples from treatments T1 and T2. In the frankfurter formulation, when reducing the fat content (by using fat replacers), the values of $\mathrm{L}^{*}$ and $\mathrm{b}^{*}$ decreased and $\mathrm{a}^{*}$ value increased, but when changed the fat level and meat content (myoglobin), several variations can be found in color [50,51]. However, Purohit et al. [52] indicated that the incorporation of non-meat ingredients often mitigates differences in color of meat products. Therefore, the different influences of antioxidant treatment in frankfurter color are due to the characteristic color of the ingredient used, and also the chemical stability of these compounds during frankfurter manufacturing processes. 


\subsection{Fatty Acid Composition and Cholesterol Content}

The total proportion of saturated, monounsaturated and polyunsaturated fatty acids in the dried murta was $21.72 \pm 1.49,15.58 \pm 0.32$ and $59.63 \pm 0.31 \mathrm{~g} / 100 \mathrm{~g}$ of total fatty acids, respectively. The predominant fatty acids in this fruit were linoleic $(\mathrm{C} 18: 2 \mathrm{n}-6)$ and oleic acid (C18:1n-9). López et al. [53] and Cabrera-Barjas [25] also reported that linoleic acid was the most abundant fatty acid in murta. Moreover, Yang et al. [54] reported that the major fatty acids in some northern berry were linoleic and linolenic acids. Therefore, the fatty acid profile observed in the present study was similar to those reported in previous studies.

Table 5 shows the fatty acid composition and cholesterol content of frankfurters of each treatment. The fatty acids C12:0, C13:0, C15:0, C17:0, C20:3n-6 and C22:6n-3 were excluded for presented a minor content in all the samples (less $0.05 \%$ ). In all the treatments, the principal fatty acids in quantitative terms were oleic acid (C18:1n-9), followed by palmitic acid (C16:0), stearic acid (C18:0) and linoleic acid (C18:2n-6). The sum of these four fatty acids represented more than $96 \%$ of the total fatty acids identified in all samples. These four main fatty acid and their contents agree with the results found by Armenteros et al. [1].

Table 5. Fatty acid profile (\% FAME) and cholesterol content (mg/100 g) of frankfurters.

\begin{tabular}{|c|c|c|c|c|}
\hline \multirow{2}{*}{ Parameter * } & \multicolumn{3}{|c|}{ Treatments 1} & \multirow{2}{*}{$p$-Value } \\
\hline & T0 & T1 & T2 & \\
\hline \multicolumn{5}{|c|}{ Fatty Acids (\% of Total FAME) } \\
\hline C14:0 & $1.42 \pm 0.03^{\mathrm{a}}$ & $1.41 \pm 0.01^{\mathrm{a}}$ & $1.31 \pm 0.01^{b}$ & 0.000 \\
\hline C16:0 & $25.86 \pm 0.61$ & $25.60 \pm 0.02$ & $26.08 \pm 0.61$ & 0.275 \\
\hline$C 16: 1 n-7$ & $0.99 \pm 0.01^{b}$ & $1.02 \pm 0.02^{\mathrm{a}}$ & $0.98 \pm 0.03^{b}$ & 0.022 \\
\hline C17:1n-7 & $0.11 \pm 0.02$ & $0.11 \pm 0.001$ & $0.11 \pm 0.02$ & 0.960 \\
\hline C18:0 & $13.32 \pm 0.61^{\mathrm{a}}$ & $12.81 \pm 0.01^{b}$ & $12.78 \pm 0.04^{b}$ & 0.031 \\
\hline $9 t-C 18: 1$ & $0.31 \pm 0.03^{a b}$ & $0.34 \pm 0.004^{\mathrm{a}}$ & $0.28 \pm 0.03^{b}$ & 0.007 \\
\hline C18:1n-9 & $45.68 \pm 1.00$ & $45.99 \pm 0.02$ & $45.95 \pm 0.61$ & 0.665 \\
\hline $9 t, 11 t-C 18: 2$ & $0.05 \pm 0.005^{b}$ & $0.06 \pm 0.005^{\mathrm{a}}$ & $0.04 \pm 0.001^{b}$ & 0.000 \\
\hline C18:2n-6 & $11.63 \pm 0.32^{b}$ & $11.80 \pm 0.12^{a b}$ & $12.03 \pm 0.09^{a}$ & 0.013 \\
\hline$C 18: 3 n-3$ & $0.10 \pm 0.005^{a}$ & $0.05 \pm 0.01^{\mathrm{b}}$ & $0.09 \pm 0.001^{a}$ & 0.000 \\
\hline $\mathrm{CLA}^{2}$ & $0.32 \pm 0.005^{\mathrm{ab}}$ & $0.30 \pm 0.02^{b}$ & $0.33 \pm 0.03^{a}$ & 0.041 \\
\hline C20:3n-3 & $0.06 \pm 0.01^{\mathrm{a}}$ & $0.04 \pm 0.01^{\mathrm{b}}$ & $0.06 \pm 0.005^{a}$ & 0.006 \\
\hline Cholesterol & $76.33 \pm 1.03^{b}$ & $84.83 \pm 1.33^{a}$ & $77.67 \pm 1.02^{b}$ & 0.000 \\
\hline
\end{tabular}

${ }^{1}$ T0: control without antioxidant, T1: chemical antioxidant (Plus Color), T2: natural antioxidant (murta). ${ }^{2}$ Sum of isomers cis- 9 trans- 11 and trans- 9 cis- 11 of conjugated linoleic acid. Different letters in the same row indicate significant differences ( $p \leq 0.05$; Tukey test); * All parameter values were presented as mean \pm standard deviation.

The antioxidant reformulation did not influence the content of oleic and palmitic acids $(p \geq 0.05)$, while decrease the stearic acid and increase the linoleic acid amounts in comparison with control samples. In the saturated fatty acids (SFA), the frankfurter reformulated with murta also presented the lowest values of the miristic (C14:0) acid. As aforementioned, the oil of murta are characterized by high amounts of unsaturated fatty acids, mainly linoleic acid (88.2\%) and oleic acid (7.7\%) [25], and as expected, the frankfurters formulated with murta promoted an increase in the linoleic acid content compared to those found in T0 and T1 $(p \leq 0.05)$ and reflected the characteristic fatty acid composition of the type of ingredients used on the frankfurter formulation. In this study, it was observed higher content of C16:1n-7 and 9t,11t-C18:2 in the frankfurters from chemical antioxidant treatment than control and murta. However, it is important to highlight that these fatty acids represent only $2.07 \%$ of lipids composition, and also that the variation, although significant, was minimal (0.01\% in $9 t, 11 t-\mathrm{C} 18: 2$ and $0.03 \%$ in C16:1n-7). In the n-3 polyunsaturated fatty acids (PUFA), control and murta frankfurters presented the highest content of $\alpha$-linolenic (C18:3n-3) and cis-11,14,17-eicosatrienoic (C20:3n-3).

On the other hand, various groups of fatty acids are considered of interest by relationship with human health. One of them is trans fatty acids (TFA). Numerous clinical studies 
have confirmed that TFA would be responsible for an increased risk of heart disease more than any other macronutrient compared on a per-calorie basis [55]. In this study, TFA levels decrease $20 \%$ in frankfurters formulated with murta in comparison with the values found in treatments without antioxidant (T0) and with chemical antioxidant incorporation (T1). Moreover, much attention has been directed towards conjugated linoleic acid (CLA) isomers cis- 9 trans- $11 /$ trans- 9 cis- 11 because they show bioactive properties by modulating inflammation and would be involved in the prevention of cardiovascular disease, diabetes, obesity and cancer [56]. Regarding this, the incorporation of murta resulted in higher CLA content in frankfurters compared with the T0 and T1 ( $p \leq 0.05)$. However, once again, although these differences were significant, the variation was minimal $(0.08 \%$ in the case of TFA and $0.03 \%$ for CLA).

Therefore, as a general conclusion, as occurs in the proximate composition, the reformulation of frankfurters with murta antioxidants causes a minimal effect in the fatty acid composition. This fact agrees with the results obtained by Armenteros et al. [1], who reported that neither the addition of the fruit extract nor the addition of antioxidants additives had a significant impact on the fatty acid profile of frankfurters. In the present study, both the low oil content of murta powder (1.5\%; Table 1) and also the low amount of this powder added to the frankfurter reformulation $(0.53 \%)$ resulted in minimal fatty acids changes and that the typical fatty acid profile of murta oil was not reflected in the frankfurters. The low changes in the individual fatty acids produced also minimal changes in the total SFA, monounsaturated fatty acids (MUFA) and PUFA contents (Figure 1). In this case, no significant differences were observed between samples of the different treatments.

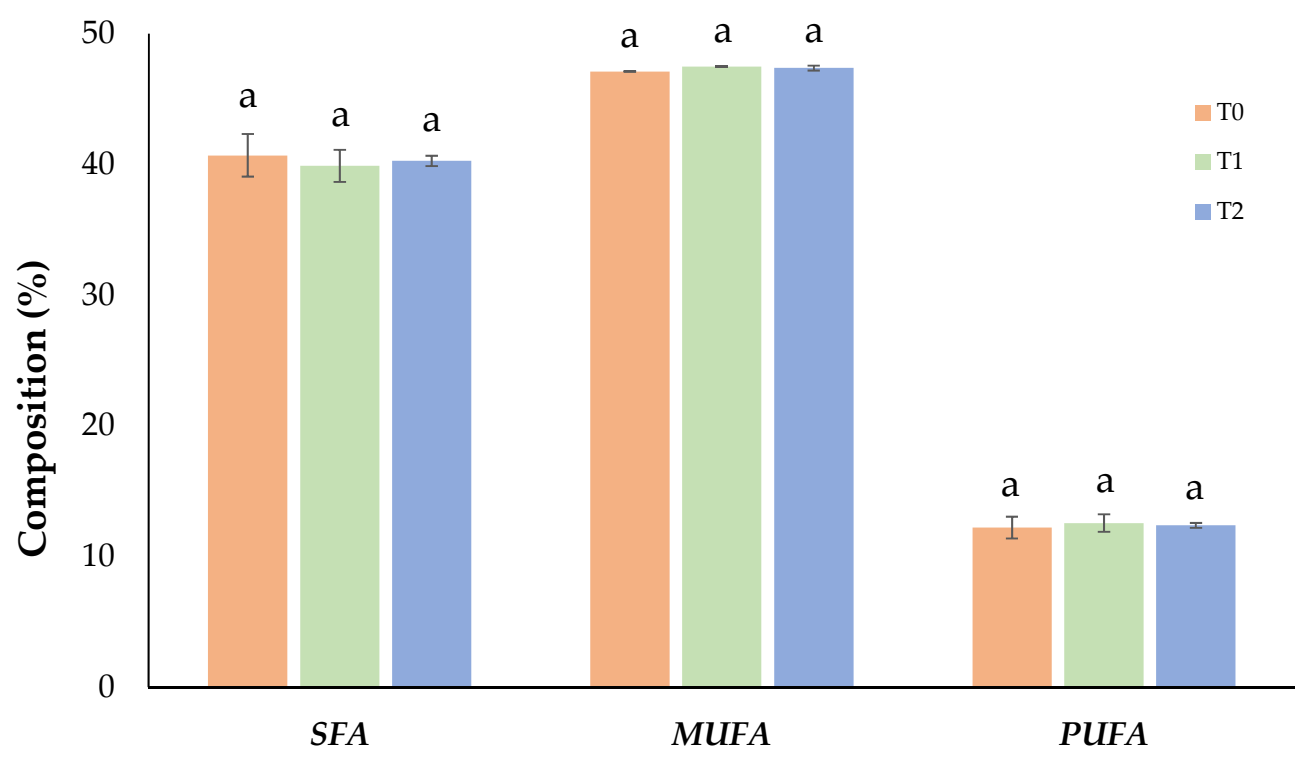

Figure 1. Fatty acid composition (total SFA, MUFA, and PUFA) of the frankfurters. T0 (frankfurter prepared without antioxidant), T1 (frankfurter prepared with Plus Color) and T2 (frankfurter prepared with murta as antioxidant). Different letters indicate a significant difference between treatments ( $p \leq 0.05$; Tukey test). Error bars correspond to standard error.

Regarding cholesterol content, murta and control frankfurters showed the same values (about $77 \mathrm{mg} / 100 \mathrm{~g}$ ), while samples formulated with chemical antioxidant presented the highest values $(84 \mathrm{mg} / 100 \mathrm{~g})$. Our values agree with those reported by other authors in frankfurters and emulsified-cooked sausages [6,57]. However, in other studies, the researchers found lower values $[58,59]$, which demonstrate that cholesterol values could be very variable between formulations. Although the sausages formulated with synthetic antioxidant (T1) presented the highest values, the cholesterol content among the three formulations was very similar (only varied about $\sim 7 \mathrm{mg} / 100 \mathrm{~g}$ ). In contrast, other authors found a significant reduction of sausages cholesterol content due to the reduction or replacement of animal fat [57-59]. However, in the present study, the cholesterol values 
did not show this behavior since the same formulation (except for antioxidants) and the same processes and conditions were used in all cases.

On the other hand, in order to assess the nutritional quality of fat, different indices based on the fatty acid composition are used. Ulbricht and Southgate [60] described seven dietary factors that have a direct influence on coronary heart disease (CHD). In this regard, saturated fatty acids (SFA) and thrombogenic SFA were described as promoters of the development of CHD. On the contrary, MUFA, PUFA of the n-6 (linoleic) acid series and the n-3 (linolenic) acid series, dietary fiber, and antioxidants are described as protective. But not all SFA act in the same way, while stearic acid is considered neutral, lauric acid (C12:0), miristic (C14:0), and palmitic acid (C16:0) produce the greatest atherogenic effect [61]. Thus, Ulbricht and Southgate [60] proposed two indices, atherogenic (AI) and thrombogenic (TI) indices, which allow for evaluating nutritional quality and health implications of fat, and the comparison of different foods considering the content of atherogenic SFA. So, high values of $\mathrm{AI}$ and TI indicates the poor nutritional quality of fat. In this sense, the addition of murta to the frankfurter formulation decreased the miristic acid (C14:0), showing the lowest value between treatments. Additionally, according to the fatty acids content, the PUFA/SFA, AI and TI index were calculated (Figure 2).

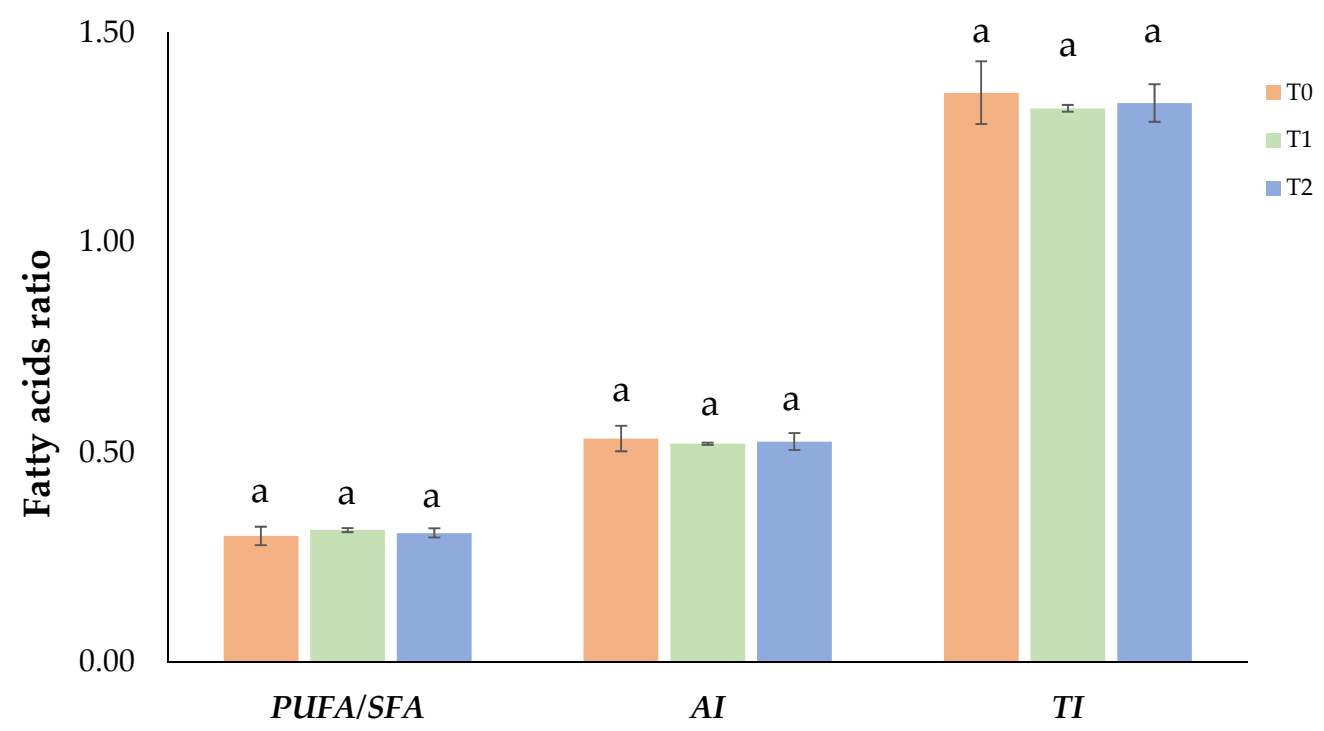

Figure 2. Fatty acid ratios and nutritional indices of the frankfurters. T0 (frankfurter prepared without antioxidant), T1 (frankfurter prepared with Plus Color) and T2 (frankfurter prepared with murta as antioxidant). Different letters indicate a significant difference between treatments ( $p \leq 0.05$; Tukey test). Error bars correspond to standard error.

One of the principal parameters to assess the nutritional quality of lipid fraction of foods is the PUFA/SFA ratio, which according to the Nutritional guidelines should be above $0.4[46,62]$. In our study, the PUFA/SFA ratio was similar among all treatments and ranged between $0.31-0.32(p \geq 0.05)$ but was lower than 0.4. Our findings are consistent with the results observed by other authors in conventional meat products [46]. According to scientific evidence, high n-6/n-3 PUFA ratios promote cardiovascular diseases, whereas increased n-3 PUFA (a low n-6/n-3 PUFA ratio) exerts a suppressive effect. The recommendation for the n- $6 / n-3$ PUFA ratio and the prevention of cardiovascular disease is to reduce this ratio to less than $4[63,64]$. In this experiment, the ratio $n-6 / n-3$ was considerably higher than 4.0 (61.4, 89.8 and 63.9 for T0. T1 and T2, respectively; data not shown). In the present study, the control and murta frankfurters presented the best $n-6 / n-3$ ratio, while the samples from chemical antioxidant had the highest values. The low amounts of n-3 fatty acids found in this research determine the high values of this ratio. Also, the lowest values of n-3 PUFA in the T1 samples make that the frankfurters from this batch presented the highest $n-6 / n-3$ ratio. Recent studies concluded that the reduction in $n-6$ and n- $6 / n-3$ 
ratio is one of the main challenges for the development of healthier meat products since meat presented relatively high values of n-6 PUFA and low amounts of n-3 PUFA [64]. This fact agrees with our results.

Regarding atherogenic (AI) and thrombogenic (TI) indices, no differences $(p>0.05)$ were found between the treatments. Therefore, from the nutritional point of view, the reformulation did not exert any change in the quality of frankfurters' fat. This is expected since, as commented above, the low amount of fat in murta powder and the low amount of this powder used in the frankfurter formulation has minimal influence in fatty acids composition, and thus in their nutritional quality. The AI of the samples ranged from 0.52 to 0.53 , while the TI values were between $1.32-1.36$. These values agree with those reported previously by Dominguez et al. [5] (AI: 0.43; TI: 0.95) and Pintado et al. [42] (AI: 0.55; TI: 1.36) in frankfurters and by De Carvalho et al. [65] in cooked lamb sausages (AI: 0.47; TI: 1.18). But not only in frankfurters or cooked sausages, since also similar values of these indices were reported in dry-cured sausages (AI: 0.42; TI:0.98) [66], burgers (AI: 0.61; TI: 1.06) [67], (AI: 0.42; TI: 0.87), (AI: 0.56; TI: 1.33) [68], (AI: 0.62; TI: 1.33) [69] or pâté (AI: 0.38; TI: 0.88) [70], (AI: 0.40; TI: 0.89) [71]. Therefore, our values agree with those reported by other authors in meat products manufactured with animal fat.

\subsection{Sensory Evaluation}

The sensory traits for the different frankfurter treatments are shown in Figure 3. The frankfurters reformulation with murta increased the scores of the four attributes evaluated with significant differences between the rest of the treatments $(p \leq 0.05)$. Additionally, in all attributes, no significant differences were observed between control (T0) and samples formulated with chemical antioxidant (T1). Regarding the odor attribute, its score was in the range of 6.0 (T1) to 6.8 (T2), flavor scores ranged from 6.0 (T0) to 6.8 (T2) and tenderness from 6.2 (T0) and 6.9 (T2). Similarly, for overall acceptability, the consumers also indicated higher scores for the frankfurters of the T2 batch (6.8) in comparison with those reported for the other two batches (6.3 for T0 and T1 samples).

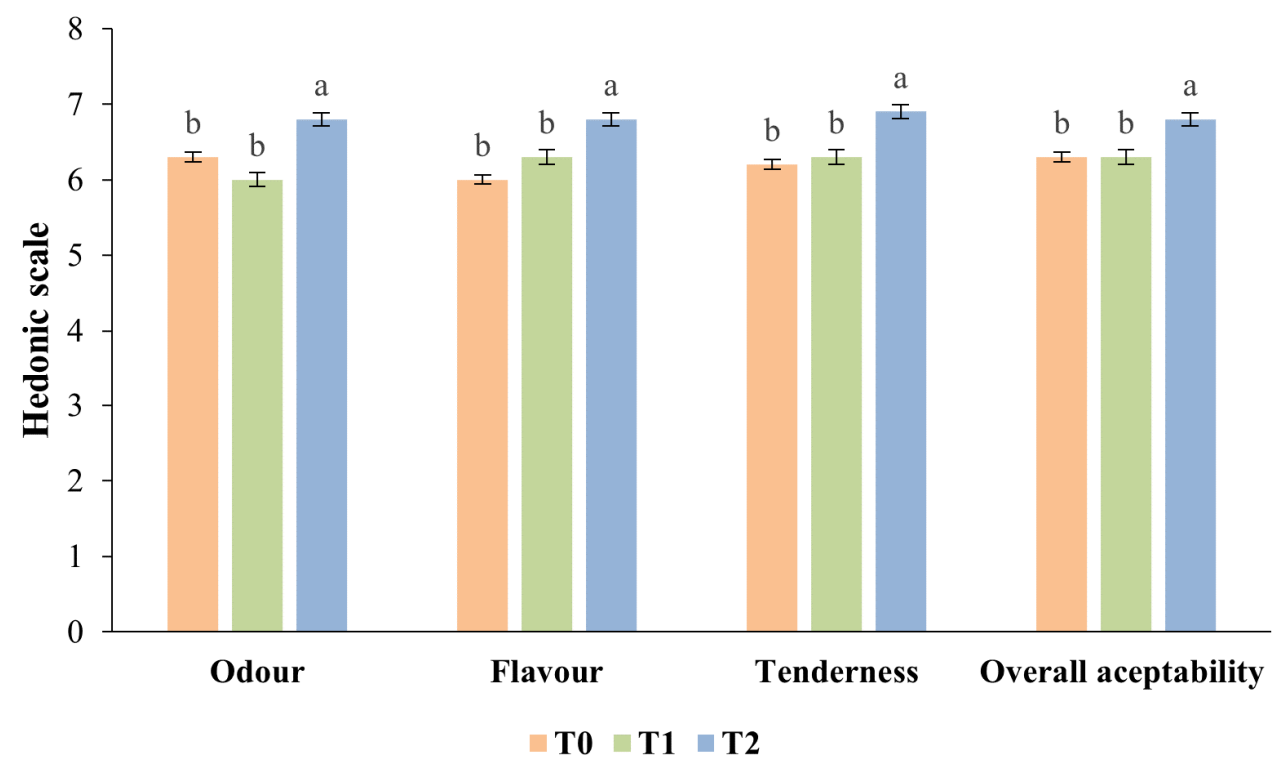

Figure 3. Sensory evaluation of frankfurters based on score acceptability (odor, tenderness, flavor and overall acceptability) of treatments T0 (frankfurter prepared without antioxidant), T1 (frankfurter prepared with Plus Color) and T2 (frankfurter prepared with murta as antioxidant). Hedonic scale from dislike extremely (1), dislike very much (2), dislike moderately (3), dislike slightly (4), like slightly (5), like moderately (6), like very much (7) and like extremely (8). Different letters indicate a significant difference between treatments $(p \leq 0.05)$. Error bars correspond to standard error $(n=130)$.

The analysis carried out on the information provided by the consumers allowed us to differentiate the frankfurters treatments and determine the acceptability and preference 
using the criteria of the consumers through a hedonic scale, in addition to providing rapid information on the capacity and potential of the frankfurter's formulations. Thus, according to the results, it can be concluded that the murta incorporation improves the frankfurters' sensory properties in comparison with control and with samples reformulated with chemical antioxidant. This can be explained by the chemical parameters of murta that contribute to the organoleptic characteristic of frankfurters and exhibits a special and surrounding aroma, and that the volatile compounds improve the odor and flavor of frankfurters. Murta, due to organoleptic characteristic, is consumed as a fresh fruit but it is also processed by the food industry for elaborating juice, jam, canned items, and liquor products [24]. During sensorial analysis, the consumers mentioned that odor and flavor were better in one treatment. According to the results obtained, the treatment mentioned corresponding to frankfurters reformulated with murta. As commented above, between control and synthetic antioxidant treatments, the consumers did not find significant differences in the attributes evaluated, suggesting that are the usual commercial product.

Additionally, according to the overall acceptability indicated by the consumers, it can be concluded that the amount of murta added to the frankfurter's formulation is appropriate. Some authors have observed in the elaboration of frankfurters with grape seed extracts added directly, that the incorporation of excessive amounts of plant extracts may result in unpleasant sensory characteristics in meat products [40]. The addition of pomace powder in a similar concentration to our study $(0.5 \%)$ did not change the sensory characteristic of emulsion-type sausage [48], which agree with our findings. In another study, the reformulation of frankfurters with vegetable oil (such as olive, grape seed, corn oil, and canola oil) and rice bran fiber showed similar or higher overall acceptability than high-fat control [47]. In general, the sensory evaluation of frankfurters of the present study indicated that all samples were acceptable, but the addition of murta improve the sensory properties of this meat product.

\section{Conclusions}

The use of murta powder in the elaboration of meat products can be a strategy to improve their chemical and organoleptic characteristics. In addition, this type of berries provides unique sensory characteristics, which are positively valued by consumers. Furthermore, the results of this study would allow to diversify the use of local bioresources and add value to traditional meat products, such as frankfurters, which represent an important source of animal protein. As a general conclusion, the use of murta powder as a natural antioxidant in the reformulation of frankfurters had minimal influence on their chemical and nutritional quality, while producing a significant improvement of sensory quality. Thus, murta powder is an excellent candidate to avoid the use of synthetic additives in meat products. However, future studies will allow understanding in detail the antioxidant effect and the possibility of using murta as an additive to increase the shelf life of frankfurters.

Author Contributions: Conceptualization, K.I. and N.S.; methodology, S.B. and E.A.P.; formal analysis, S.B., K.I., G.S., E.S. and J.Q.; data curation, S.B., K.I. and R.D.; writing-original draft preparation, S.B., K.I and R.D.; writing-review and editing, J.M.L., R.D., E.A.P., E.M.S., S.C.A., M.R., J.F.R. and M.A.T.; supervision, N.S. All authors have read and agreed to the published version of the manuscript.

Funding: This research was funded by Fundación para la Innovación Agraria (FIA), Ministerio de Agricultura de Chile, Project FIA-PYT-2016-0662 and ANID (Project ARIII7005). The APC was funded by Healthy Meat network (CYTED ref. 119RT0568).

Institutional Review Board Statement: Not applicable.

Informed Consent Statement: Informed consent was obtained from all subjects involved in the study.

Data Availability Statement: All data obtained in this study are available in the article. 
Acknowledgments: The authors thanks to support of Dirección de Investigación, Universidad de La Frontera and to GAIN (Axencia Galega de Innovación) for supporting this study (grant number IN607A2019/01). Authors are members of the Healthy Meat network, funded by CYTED (ref. 119RT0568).

Conflicts of Interest: The authors declare no conflict of interest.

\section{References}

1. Armenteros, M.; Morcuende, D.; Ventanas, S.; Estévez, M. Application of Natural Antioxidants from Strawberry Tree (Arbutus unedo L.) and Dog Rose (Rosa canina L.) to Frankfurters Subjected to Refrigerated Storage. J. Integr. Agric. 2013, 12, $1972-1981$. [CrossRef]

2. Fernández-López, J.; Lucas-González, R.; Viuda-Martos, M.; Sayas-Barberá, E.; Navarro, C.; Haros, C.M.; Pérez-Álvarez, J.A. Chia (Salvia hispanica L.) products as ingredients for reformulating frankfurters: Effects on quality properties and shelf-life. Meat Sci. 2019, 156, 139-145. [CrossRef] [PubMed]

3. Domínguez, R.; Munekata, P.E.; Pateiro, M.; López-Fernández, O.; Lorenzo, J.M. Immobilization of oils using hydrogels as strategy to replace animal fats and improve the healthiness of meat products. Curr. Opin. Food Sci. 2021, 37, 135-144. [CrossRef]

4. El Instituto Nacional de Estadísticas. Informe Annual de Cecinas $N^{\circ} 6$ diciembre de 2019; El Instituto Nacional de Estadísticas: Valdivia, Chile, 2019. Available online: https://regiones.ine.cl/documentos/default-source/region-xiv/estadisticas-r14/boletinesinformativos/pecuario/cecinas/cecinas---periodo-2019.pdf (accessed on 14 September 2021).

5. Domínguez, R.; Pateiro, M.; Agregán, R.; Lorenzo, J.M. Effect of the partial replacement of pork backfat by microencapsulated fish oil or mixed fish and olive oil on the quality of frankfurter type sausage. J. Food Sci. Technol. 2017, 54, 26-37. [CrossRef] [PubMed]

6. Choi, Y.-S.S.; Choi, J.-H.H.; Han, D.-J.J.; Kim, H.-Y.Y.; Lee, M.-A.A.; Jeong, J.-Y.Y.; Chung, H.-J.J.; Kim, C.-J.J. Effects of replacing pork back fat with vegetable oils and rice bran fiber on the quality of reduced-fat frankfurters. Meat Sci. 2010, 84, 557-563. [CrossRef] [PubMed]

7. Ospina-E, J.C.; Rojano, B.; Ochoa, O.; Pérez-Álvarez, J.A.; Fernández-López, J. Development of frankfurter-type sausages with healthy lipid formulation and their nutritional, sensory and stability properties. Eur. J. Lipid Sci. Technol. 2015, 117, 122-131. [CrossRef]

8. Domínguez, R.; Pateiro, M.; Gagaoua, M.; Barba, F.J.; Zhang, W.; Lorenzo, J.M. A Comprehensive Review on Lipid Oxidation in Meat and Meat Products. Antioxidants 2019, 8, 429. [CrossRef] [PubMed]

9. Firuzi, M.R.; Niakousari, M.; Eskandari, M.H.; Keramat, M.; Gahruie, H.H.; Khaneghah, A.M. Incorporation of pomegranate juice concentrate and pomegranate rind powder extract to improve the oxidative stability of frankfurter during refrigerated storage. LWT 2019, 102, 237-245. [CrossRef]

10. Domínguez, R.; Munekata, P.E.S.; Pateiro, M.; Maggiolino, A.; Bohrer, B.; Lorenzo, J.M. Red Beetroot. A Potential Source of Natural Additives for the Meat Industry. Appl. Sci. 2020, 10, 8340. [CrossRef]

11. Domínguez, R.; Gullón, P.; Pateiro, M.; Munekata, P.E.S.; Zhang, W.; Lorenzo, J.M. Tomato as Potential Source of Natural Additives for Meat Industry. A Review. Antioxidants 2020, 9, 73. [CrossRef] [PubMed]

12. Lorenzo, J.M.; Pateiro, M.; Domínguez, R.; Barba, F.J.; Putnik, P.; Kovačević, D.B.; Shpigelman, A.; Granato, D.; Franco, D. Berries extracts as natural antioxidants in meat products: A review. Food Res. Int. 2018, 106, 1095-1104. [CrossRef] [PubMed]

13. Munekata, P.E.S.; Gullón, B.; Pateiro, M.; Tomasevic, I.; Domínguez, R.; Lorenzo, J.M. Natural Antioxidants from Seeds and Their Application in Meat Products. Antioxidants 2020, 9, 815. [CrossRef] [PubMed]

14. Munekata, P.E.S.; Domínguez, R.; Campagnol, P.C.B.; Franco, D.; Trindade, M.A.; Lorenzo, J.M. Effect of natural antioxidants on physicochemical properties and lipid stability of pork liver pâté manufactured with healthy oils during refrigerated storage. $J$. Food Sci. Technol. 2017, 54, 4324-4334. [CrossRef] [PubMed]

15. Domínguez, R.; Zhang, L.; Rocchetti, G.; Lucini, L.; Pateiro, M.; Munekata, P.E.S.; Lorenzo, J.M. Elderberry (Sambucus nigra L.) as potential source of antioxidants. Characterization, optimization of extraction parameters and bioactive properties. Food Chem. 2020, 330, 127266. [CrossRef] [PubMed]

16. Pateiro, M.; Munekata, P.E.S.; Cittadini, A.; Domínguez, R.; Lorenzo, J.M. Metallic-based salt substitutes to reduce sodium content in meat products. Curr. Opin. Food Sci. 2021, 38, 21-31. [CrossRef]

17. Domínguez, R.; Bohrer, B.; Munekata, P.E.S.; Pateiro, M.; Lorenzo, J.M. Recent Discoveries in the Field of Lipid Bio-Based Ingredients for Meat Processing. Molecules 2021, 26, 190. [CrossRef] [PubMed]

18. Pateiro, M.; Vargas, F.C.; Chincha, A.A.; Sant'Ana, A.S.; Strozzi, I.; Rocchetti, G.; Barba, F.J.; Domínguez, R.; Lucini, L.; Sobral, P.J.D.A.; et al. Guarana seed extracts as a useful strategy to extend the shelf life of pork patties: UHPLC-ESI/QTOF phenolic profile and impact on microbial inactivation, lipid and protein oxidation and antioxidant capacity. Food Res. Int. 2018, 114, 55-63. [CrossRef]

19. Lorenzo, J.M.; Vargas, F.C.; Strozzi, I.; Pateiro, M.; Furtado, M.M.; Sant'Ana, A.S.; Rocchetti, G.; Barba, F.J; Dominguez, R.; Lucini, L.; et al. Influence of pitanga leaf extracts on lipid and protein oxidation of pork burger during shelf-life. Food Res. Int. 2018, 114, 47-54. [CrossRef]

20. De Carvalho, F.A.L.; Munekata, P.E.; de Oliveira, A.L.; Pateiro, M.; Domínguez, R.; Trindade, M.A.; Lorenzo, J.M. Turmeric (Curcuma longa L.) extract on oxidative stability, physicochemical and sensory properties of fresh lamb sausage with fat replacement by tiger nut (Cyperus esculentus L.) oil. Food Res. Int. 2020, 136, 109487. [CrossRef] [PubMed] 
21. Antonić, B.; Jančíková, S.; Dordević, D.; Tremlová, B. Grape Pomace Valorization: A Systematic Review and Meta-Analysis. Foods 2020, 9, 1627. [CrossRef] [PubMed]

22. Munekata, P.E.S.; Pateiro, M.; Bellucci, E.R.B.; Domínguez, R.; Barretto, A.C.D.S.; Lorenzo, J.M. Strategies to increase the shelf life of meat and meat products with phenolic compounds. In Advances Food Nutrition Research; Academic Press Inc.: Cambridge, MA, USA, 2021. [CrossRef]

23. Rubilar, M.; Pinelo, M.; Ihl, M.; Scheuermann, E.; Sineiro, J.; Nuñez, M.J. Murta Leaves (Ugni molinae Turcz) as a Source of Antioxidant Polyphenols. J. Agric. Food Chem. 2006, 54, 59-64. [CrossRef] [PubMed]

24. Scheuermann, E.; Seguel, I.; Montenegro, A.; Bustos, R.O.; Hormazábal, E.; Quiroz, A. Evolution of aroma compounds of murtilla fruits (Ugni molinae Turcz) during storage. J. Sci. Food Agric. 2008, 88, 485-492. [CrossRef]

25. Cabrera-Barjas, G.; Quezada, A.; Bernardo, Y.; Moncada, M.; Zúñiga, E.; Wilkens, M.; Giordano, A.; Nesic, A.; Delgado, N. Chemical composition and antibacterial activity of red murta (Ugni molinae Turcz.) seeds: An undervalued Chilean resource. J. Food Meas. Charact. 2020, 14, 1810-1821. [CrossRef]

26. Peña-Cerda, M.; Arancibia-Radich, J.; Valenzuela-Bustamante, P.; Pérez-Arancibia, R.; Barriga, A.; Seguel, I.; García, L.; Delporte, C. Phenolic composition and antioxidant capacity of Ugni molinae Turcz. leaves of different genotypes. Food Chem. 2017, 215, 219-227. [CrossRef] [PubMed]

27. Speisky, H.; Lóopez-Alarcón, C.; Gómez, M.; Fuentes, J.; Sandoval-Acuña, C. First Web-Based Database on Total Phenolics and Oxygen Radical Absorbance Capacity (ORAC) of Fruits Produced and Consumed within the South Andes Region of South America. J. Agric. Food Chem. 2012, 60, 8851-8859. [CrossRef]

28. De Dicastillo, C.L.; Bustos, F.; Valenzuela, X.; López-Carballo, G.; Vilariño, J.M.; Galotto, M.J. Chilean berry Ugni molinae Turcz. fruit and leaves extracts with interesting antioxidant, antimicrobial and tyrosinase inhibitory properties. Food Res. Int. 2017, 102, 119-128. [CrossRef] [PubMed]

29. National Institute of Standardization. Moisture Determination, NCh841:1978; Instituto Nacional de Normalización: Santiago, Chile, 1978. Available online: https:/ / ecommerce.inn.cl/nch841197842569 (accessed on 14 September 2021).

30. ISO. ISO 5983-2:2009 Animal Feeding Stuffs—Determination of Nitrogen Content and Calculation of Crude Protein Content-Part 2: Block Digestion and Steam DISTILLATION Method; International Organization for Standardization: Genéve, Switzerland, 2009. Available online: https:/ / www.iso.org/standard/52199.html (accessed on 14 September 2021).

31. AOAC International. Official Methods of Analysis of AOAC International. Volume 1, Agricultural Chemicals, Contaminants, Drugs; AOAC International: Rockville, MD, USA, 2000; ISBN 0935584676.

32. Gafta Method 9.0: Crude Fibre in Feedingstuffs; London, UK. 2018. Available online: https://www.gafta.com/write/MediaUploads/ Contracts /2014/method_9.0_2014.pdf (accessed on 14 September 2021).

33. Horwitz, W.; Latimer, G. AOAC Official Methods of Analysis of AOAC International; AOAC International: Rockville, MD, USA, 2005.

34. Dzudie, T.; Scher, J.; Tchiégang, C.; Hardy, J. Effect of Fat Sources on the Physico-Chemical Nutritional and Textural Properties of Beef Sausages. J. Food Technol. 2005, 3, 220-225.

35. Folch, J.; Lees, M.; Stanley, G.S. A Simple Method for the Isolation and Purification of Total Lipides from Animal Tissues. J. Biol. Chem. 1957, 226, 497-509. [CrossRef]

36. Fletouris, D.J.; Botsoglou, N.A.; Psomas, I.E.; Mantis, A.I. Rapid Determination of Cholesterol in Milk and Milk Products by Direct Saponification and Capillary Gas Chromatography. J. Dairy Sci. 1998, 81, 2833-2840. [CrossRef]

37. National Institute of Standardization. Sensorial Food Analysis NCh-ISO6658:2016; Instituto Nacional de Normalización: Santiago, Chile, 2016. Available online: https:/ / ecommerce.inn.cl/nch-iso6658201652982 (accessed on 14 September 2021).

38. Guerrero, L. Estudios de consumidores: Análisis de los errores más habituales. In Avances en Análisis Sensorial; Almeida, T.C.A., Hough, G., Damasio, M.H., da Silva, M.A.A.P., Eds.; Varela Editora: Sao Paulo, Brazil, 1999; pp. 121-129.

39. Amerine, M.A.; Pangborn, R.M.; Roessler, E.B. Principles of Sensory Evaluation of Food, 1st ed.; Academic Press: Cambridge, MA, USA, 1965; ISBN 978-0120561506.

40. Pintado, T.; Muñoz-González, I.; Salvador, M.; Ruiz-Capillas, C.; Herrero, A.M. Phenolic compounds in emulsion gel-based delivery systems applied as animal fat replacers in frankfurters: Physico-chemical, structural and microbiological approach. Food Chem. 2021, 340, 128095. [CrossRef] [PubMed]

41. Rahman, M.S.; Seo, J.-K.; Zahid, M.A.; Park, J.-Y.; Choi, S.-G.; Yang, H.-S. Physicochemical properties, sensory traits and storage stability of reduced-fat frankfurters formulated by replacing beef tallow with defatted bovine heart. Meat Sci. 2019, 151, 89-97. [CrossRef] [PubMed]

42. Pintado, T.; Herrero, A.M.; Ruiz-Capillas, C.; Triki, M.; Carmona, P.; Jimenez-Colmenero, F. Effects of emulsion gels containing bioactive compounds on sensorial, technological, and structural properties of frankfurters. Food Sci. Technol. Int. 2016, 22, 132-145. [CrossRef] [PubMed]

43. Schnettler, B.; Ares, G.; Sepúlveda, N.; Bravo, S.; Villalobos, B.; Hueche, C.; Lobos, G. Are consumers willing to pay more for reformulated processed meat products in the context of the implementation of nutritional warnings? Case study with frankfurters in Chile. Meat Sci. 2019, 152, 104-108. [CrossRef] [PubMed]

44. Cittadini, A.; Domínguez, R.; Gómez, B.; Pateiro, M.; Pérez-Santaescolástica, C.; López-Fernández, O.; Sarriés, M.V.; Lorenzo, J.M. Effect of $\mathrm{NaCl}$ replacement by other chloride salts on physicochemical parameters, proteolysis and lipolysis of dry-cured foal “cecina". J. Food Sci. Technol. 2020, 57, 1628-1635. [CrossRef] [PubMed] 
45. Domínguez, R.; Pateiro, M.; Pérez-Santaescolástica, C.; Munekata, P.E.S.; Lorenzo, J.M. Salt reduction strategies in meat products made from whole pieces. In Strategies for Obtaining Healthier Foods; Lorenzo, J.M., Carballo, F.J., Eds.; Nova Science Publishers: Hapog, NY, USA, 2017; pp. 267-289, ISBN 978-1-53612-159-9.

46. López-López, I.; Cofrades, S.; Jiménez-Colmenero, F. Low-fat frankfurters enriched with n-3 PUFA and edible seaweed: Effects of olive oil and chilled storage on physicochemical, sensory and microbial characteristics. Meat Sci. 2009, 83, 148-154. [CrossRef] [PubMed]

47. Choi, Y.-S.; Park, K.-S.; Kim, H.-W.; Hwang, K.-E.; Song, D.-H.; Choi, M.-S.; Lee, S.-Y.; Paik, H.-D.; Kim, C.-J. Quality characteristics of reduced-fat frankfurters with pork fat replaced by sunflower seed oils and dietary fiber extracted from makgeolli lees. Meat Sci. 2013, 93, 652-658. [CrossRef] [PubMed]

48. Savadkoohi, S.; Hoogenkamp, H.; Shamsi, K.; Farahnaky, A. Color, sensory and textural attributes of beef frankfurter, beef ham and meat-free sausage containing tomato pomace. Meat Sci. 2014, 97, 410-418. [CrossRef]

49. Ramirez, J.E.; Zambrano, R.; Sepúlveda, B.; Kennelly, E.J.; Simirgiotis, M.J. Anthocyanins and antioxidant capacities of six Chilean berries by HPLC-HR-ESI-ToF-MS. Food Chem. 2015, 176, 106-114. [CrossRef] [PubMed]

50. Ayo, J.; Carballo, J.; Solas, M.T.; Jiménez-Colmenero, F. Physicochemical and sensory properties of healthier frankfurters as affected by walnut and fat content. Food Chem. 2008, 107, 1547-1552. [CrossRef]

51. Jiménez-Colmenero, F.; Cofrades, S.; López-López, I.; Ruiz-Capillas, C.; Pintado, T.; Solas, M.T. Technological and sensory characteristics of reduced/low-fat, low-salt frankfurters as affected by the addition of konjac and seaweed. Meat Sci. 2010, 84, 356-363. [CrossRef] [PubMed]

52. Purohit, A.S.; Reed, C.; Mohan, A. Development and evaluation of quail breakfast sausage. LWT Food Sci. Technol. 2016, 69, 447-453. [CrossRef]

53. López, J.; Ah-Hen, K.S.; Vega-Gálvez, A.; Morales, A.; García-Segovia, P.; Uribe, E. Effects of drying methods on quality attributes of murta (Ugni molinae Turcz) berries: Bioactivity, nutritional aspects, texture profile, microstructure and functional properties. J. Food Process Eng. 2017, 40, e12511. [CrossRef]

54. Yang, B.; Ahotupa, M.; Määttä, P.; Kallio, H. Composition and antioxidative activities of supercritical $\mathrm{CO}_{2}$-extracted oils from seeds and soft parts of northern berries. Food Res. Int. 2011, 44, 2009-2017. [CrossRef]

55. Gómez-Cortés, P.; Juárez, M.; de la Fuente, M.A. Milk fatty acids and potential health benefits: An updated vision. Trends Food Sci. Technol. 2018, 81, 1-9. [CrossRef]

56. Van Wijlen, R.P.J.; Colombani, P.C. Grass-based ruminant production methods and human bioconversion of vaccenic acid with estimations of maximal dietary intake of conjugated linoleic acids. Int. Dairy J. 2010, 20, 433-448. [CrossRef]

57. Nacak, B.; Öztürk-Kerimoğlu, B.; Yıldız, D.; Çağındı, Ö.; Serdaroğlu, M. Peanut and linseed oil emulsion gels as potential fat replacer in emulsified sausages. Meat Sci. 2021, 176, 108464. [CrossRef]

58. Franco, D.; Martins, A.J.; López-Pedrouso, M.; Purriños, L.; Cerqueira, M.A.; Vicente, A.A.; Pastrana, L.M.; Zapata, C.; Lorenzo, J.M. Strategy towards Replacing Pork Backfat with a Linseed Oleogel in Frankfurter Sausages and Its Evaluation on Physicochemical, Nutritional, and Sensory Characteristics. Foods 2019, 8, 366. [CrossRef]

59. Belichovska, D.; Pejkovski, Z.; Uzunoska, Z.; Silovska-Nikolova, A.; Belichovska, K. Effect of vegetable oils on fatty acid composition and cholesterol content of chicken frankfurters. In Proceedings of the OP Conference Series: Earth and Environmental Science, Zlatibor, Serbia, 1-4 October 2017; Volume 85, p. 12059. Available online: https://iopscience.iop.org/article/10.1088/17 55-1315/85/1/012059 (accessed on 14 September 2021).

60. Ulbricht, T.L.V.; Southgate, D.A.T. Coronary heart disease: Seven dietary factors. Lancet 1991, 338, 985-992. [CrossRef]

61. Hu, F.; Manson, J.; Willett, W. Types of Dietary Fat and Risk of Coronary Heart Disease: A Critical Review. J. Am. Coll. Nutr. 2001, 20, 5-19. [CrossRef]

62. Wood, J.D.; Richardson, R.I.; Nute, G.R.; Fisher, A.V.; Campo, M.M.; Kasapidou, E.; Sheard, P.R.; Enser, M. Effects of fatty acids on meat quality: A review. Meat Sci. 2004, 66, 21-32. [CrossRef]

63. Simopoulos, A.P. Omega-6/Omega-3 Essential Fatty Acid Ratio and Chronic Diseases. Food Rev. Int. 2004, 20, 77-90. [CrossRef]

64. Vargas-Ramella, M.; Munekata, P.E.S.; Pateiro, M.; Franco, D.; Campagnol, P.C.B.; Tomasevic, I.; Domínguez, R.; Lorenzo, J.M. Physicochemical Composition and Nutritional Properties of Deer Burger Enhanced with Healthier Oils. Foods 2020, 9, 571. [CrossRef] [PubMed]

65. De Carvalho, F.A.L.; Munekata, P.E.S.; Pateiro, M.; Campagnol, P.C.B.; Domínguez, R.; Trindade, M.A.; Lorenzo, J.M. Effect of replacing backfat with vegetable oils during the shelf-life of cooked lamb sausages. LWT 2020, 122, 109052. [CrossRef]

66. Lorenzo, J.M.; Munekata, P.E.S.; Pateiro, M.; Campagnol, P.C.B.; Domínguez, R. Healthy Spanish salchichón enriched with encapsulated n-3 long chain fatty acids in konjac glucomannan matrix. Food Res. Int. 2016, 89, 289-295. [CrossRef]

67. Cittadini, A.; Munekata, P.E.S.; Pateiro, M.; Sarriés, M.V.; Domínguez, R.; Lorenzo, J.M. Physicochemical composition and nutritional properties of foal burgers enhanced with healthy oil emulsion hydrogels. Int. J. Food Sci. Technol. 2021. [CrossRef]

68. Barros, J.C.; Munekata, P.E.S.; de Carvalho, F.A.L.; Domínguez, R.; Trindade, M.A.; Pateiro, M.; Lorenzo, J.M. Healthy beef burgers: Effect of animal fat replacement by algal and wheat germ oil emulsions. Meat Sci. 2021, 173, 108396. [CrossRef]

69. Barros, J.C.; Munekata, P.E.S.; De Carvalho, F.A.L.; Pateiro, M.; Barba, F.J.; Domínguez, R.; Trindade, M.A.; Lorenzo, J.M. Use of Tiger Nut (Cyperus esculentus L.) Oil Emulsion as Animal Fat Replacement in Beef Burgers. Foods 2020, 9, 44. [CrossRef] 
70. Domínguez, R.; Pateiro, M.; Munekata, P.E.S.; Campagnol, P.C.B.; Lorenzo, J.M. Influence of partial pork backfat replacement by fish oil on nutritional and technological properties of liver pâté. Eur. J. Lipid Sci. Technol. 2016, 119. [CrossRef]

71. Lorenzo, J.M.; Domínguez, R.; Agregán, R.; Gonçalves, A. Effect of fat replacement by olive oil on the physico-chemical properties, fatty acids, cholesterol and tocopherol content of pâté. Grasas Aceites 2016, 67, e133. [CrossRef] 